\title{
Síndrome da Infusão do Propofol ${ }^{\star}$ Propofol Infusion Syndrome
}

\author{
Fabiano Timbó Barbosa, TSA ${ }^{1}$
}

RESUMO

Barbosa FT — Síndrome da Infusão do Propofol.

JUSTIFICATIVA E OBJETIVOS: A síndrome da infusão do propofol tem sido descrita como uma síndrome rara e quase sempre fatal que ocorre após infusão prolongada desse fármaco. Ela pode resultar em acidose metabólica grave, rabdomiólise, colapso cardiovascular e morte. O objetivo deste artigo foi mostrar aspectos relacionados com a síndrome da infusão do propofol por meio da revisão de literatura.

CONTEÚDO: Estão definidas as características da síndrome da infusão do propofol quanto à fisiopatologia, características clínicas, tratamento e recomendações de dose para pacientes gravemente enfermos.

CONCLUSÕES: O propofol deve ser usado com cautela quando se planeja seu uso sob regime de infusão contínua por períodos prolongados. O surgimento de sinais sugestivos da síndrome da infusão do propofol indica a suspensão imediata do fármaco e início de medidas de suporte.

Unitermos: ANESTÉSICO, Venoso, propofol; COMPLICAÇÕES: síndrome da infusão do propofol.

\section{SUMMARY}

Barbosa FT — Propofol Infusion Syndrome.

BACKGROUND AND OBJECTIVES: Propofol infusion syndrome has been described as a rare, and frequently fatal, syndrome that occurs after prolonged infusion of this drug. It might result in severe metabolic acidosis, rhabdomyolysis, cardiovascular failure, and death. The objective of this report was to review the literature to present aspects related to the propofol infusion syndrome.

CONTENTS: The physiopathology, clinical characteristics, and treatment, of the propofol infusion syndrome as well as dose recommendations for severely ill patients are presented here.

Recebido do (Received from) Hospital Escola Doutor José Carneiro

1. Anestesiologista da Unidade de Emergência Dr. Armando Lages e do Hospital Escola Doutor José Carneiro; Médico Intensivista da Clínica Santa Juliana;

Tutor da Liga de Anestesia, Dor e Terapia Intensiva de Alagoas

Apresentado (Submitted) em 31 de agosto de 2006

Aceito (Accepted) para publicação em 25 de junho de 2007

Endereço para correspondência (Correspondence to):

Fabiano Timbó Barbosa

Rua Comendador Palmeira, 113/202

Edifício Erich Fromm - Farol

57051-150 Maceió, AL

E-mail: fabianotimbo@yahoo.com.br

C Sociedade Brasileira de Anestesiologia, 2007
CONCLUSIONS: Propofol should be used with caution when it is administered as continuous infusion for prolonged periods of time. The development of signs suggestive of the propofol infusion syndrome indicates the drug should be discontinued immediately and support measures instituted.

Key Words: ANESTHETICS, Intravenous, propofol; COMPLICATIONS: propofol infusion syndrome.

\section{INTRODUÇÃO}

O propofol foi introduzido na prática clínica em 1977 para uso exclusivo em anestesia como agente indutor por via venosa ${ }^{1}$. O rápido despertar dos pacientes mesmo após infusões prolongadas chamou a atenção dos pesquisadores para outros usos fora da anestesia ${ }^{1}$. Com o passar dos anos o fármaco foi tomando o lugar dos barbitúricos para sedar pacientes submetidos à ventilação mecânica em unidade de terapia intensiva, com a vantagem de conferir proteção encefálica aos pacientes hemodinamicamente instáveis ${ }^{2}$.

Quando o fármaco começou a ser utilizado em maior escala surgiram os primeiros relatos compatíveis com a síndrome da infusão do propofol (SIP) com alto índice de mortalidade ${ }^{1}$.

\section{PROPRIEDADES FARMACOCINÉTICAS E FARMACODINÂMICAS DO PROPOFOL}

O propofol, 2,6 diisopropilfenol, é um composto químico relativamente insolúvel em água ${ }^{3}$. É comercializado a $1 \%$ ou a $2 \%$ em emulsão leitosa branca contendo óleo de soja $10 \%$, glicerol $2,25 \%$ e $1,2 \%$ de fosfato de ovos purificados ${ }^{4}$. A presença de produtos orgânicos torna possível a contaminação da solução, porém a adição de EDTA trouxe mais segurança à sua administração ${ }^{4,5}$.

Alguns modelos farmacocinéticos sugeriram uma meia-vida de distribuição entre dois a quatro minutos e de uma a três horas para a meia-vida de eliminação $\left(T_{1 / 2} \beta\right)^{4,5}$. Possui metabolização hepática e extra-hepática ${ }^{3-5}$, provavelmente pulmão ${ }^{3}$, porque a sua taxa de degradação excede o fluxo sangüíneo hepático ${ }^{4,5}$. Forma sulfatos e glicuronídios que são inativos ${ }^{4,5}$. Em caso de hepatopatia, a sua $T_{1 / 2} \beta$ apresenta-se discretamente elevada ${ }^{4}$.

A sua eliminação é urinária e em caso de doenças renais a sua farmacocinética pouco se altera ${ }^{4-6}$

As crianças necessitam de doses maiores em virtude do maior volume de distribuição no compartimento central e do maior clearance, ocorrendo o oposto nos idosos ${ }^{4,5}$ 
O propofol possui mais de um mecanismo de ação proposto. Ele potencializa a ação inibitória central do ácido gamaaminobutírico em seu receptor tipo A, bloqueia o canal iônico no tecido cortical cerebral e nos receptores nicotínicos centrais, e exerce efeito inibitório sobre a sinalização de lisofosfatidato em receptores de mediadores lipídicos ${ }^{3}$.

Exerce ação depressora no sistema cardiovascular por ação direta e diminuição do tônus das catecolaminas além de inibir o barorreceptor ${ }^{3-5}$. Tem ação depressora na musculatura lisa dos vasos e reduz a pré e a pós-carga ${ }^{4}$.

O propofol reduz a pressão intracraniana, bem como diminui o fluxo sangüíneo encefálico e o consumo metabólico de oxigênio cerebral com atividade protetora do sistema nervoso central ${ }^{3-5}$. Porém também pode diminuir a pressão de perfusão encefálica por comprometimento hemodinâmico ${ }^{4}$. Mantém a reatividade dos vasos cerebrais ao gás carbônico $\left(\mathrm{CO}_{2}\right)$ e a auto-regulação cerebral ${ }^{3-5}$. As evidências mostraram que ele tem propriedades anticonvulsivantes, embora haja controvérsias quanto a isso ${ }^{4}$.

Ocorre depressão respiratória central, diminuição da resposta respiratória ao $\mathrm{CO}_{2}$ e hipóxia ${ }^{3-5}$. Os pacientes com doença pulmonar obstrutiva crônica apresentam broncodilatação e não há inibição da vasoconstrição pulmonar hipóxica ${ }^{3}$.

A sua ação no sistema imune é controversa. Alguns autores sugeriram ação benéfica em pacientes com endotoxemia, porém outros mostraram diminuição da formação da interleucina-8 com inibição do sistema imunológico ${ }^{4,5}$.

\section{SÍNDROME DA INFUSÃO DO PROPOFOL}

É um conjunto de eventos adversos, quase sempre de evolução fatal, que ocorrem após infusão contínua de altas doses de propofol. Pode acometer adultos e crianças embora pareça ser mais relatada em crianças ${ }^{1}$.

As alterações clínicas e laboratoriais relacionadas com a síndrome são falência cardíaca ${ }^{1,6-8}$, disritmias cardíacas ${ }^{1}$, acidose metabólica ${ }^{1,8}$, hipertrigliceridemia ${ }^{6,7}$, rabdomiólise ${ }^{6-8}$ e insuficiência renal ${ }^{6,8}$. Também ocorre infiltração de gordura no fígado ${ }^{1,6}$, nos pulmões e em outros órgãos ${ }^{6}$. A biópsia muscular pode evidenciar áreas de necrose acompanhada de áreas em regeneração compatível com mionecrose ${ }^{1}$.

A fisiopatologia da SIP ainda não está totalmente esclarecida. Algumas teorias propostas são: inibição da atividade mitocondrial por redução da atividade da citocromo $\mathrm{C}$ oxidase ${ }^{1,10}$ e por falha na oxidação dos ácidos graxos ${ }^{8-10}$, bloqueio dos receptores beta-adrenérgicos ${ }^{8,10}$ e pela presença de um metabólito com efeito tóxico nos tecidos ${ }^{1,10}$. Essa última hipótese não é aceita por todos os autores como plausível, pois já existem evidências de que os metabólitos conhecidos sejam desprovidos de atividade clinicamente significativa ${ }^{1}$.

As doses citadas na literatura como desencadeadoras da SIP são maiores que $5 \mathrm{mg} \cdot \mathrm{kg}^{-1} \cdot \mathrm{h}^{-1}$ por período superior a 48 horas ${ }^{2,6,10}$. Embora essa seja a descrição clássica já foi relatado caso em adulto, com altas doses após 12 horas, caso em criança após seis horas ${ }^{8}$ e caso após quatro horas durante a anestesia após o uso acidental de $44,7 \mathrm{mg} \cdot \mathrm{kg}^{-1} \cdot \mathrm{h}^{-1}$ em uma criança de 6 meses ${ }^{7}$.

Os principais fatores de risco associados ao aparecimento da síndrome parecem ser a dose e o tempo de uso e, é possível, também a concentração da solução empregada ${ }^{1}$. Recentemente o uso concomitante dos corticosteróides ${ }^{8}$ ou das aminas vasoativas ${ }^{9} \mathrm{com}$ o propofol também tem sido implicado como fator predisponente. Os elevados níveis de catecolaminas têm sido relacionados com a disfunção ventricular que ocorreu em alguns casos ${ }^{9}$.

O tratamento da SIP é realizado com a suspensão imediata do fármaco, medidas de suporte e diálise. Quando a diálise não pode ser empregada, a mortalidade chega a 100\% ${ }^{1}$.

Sheridan e col. ${ }^{11}$, em seu trabalho com pacientes pediátricos queimados, utilizaram infusão contínua de propofol com dose média de $3,6 \pm 2,9 \mathrm{mg} \cdot \mathrm{kg}^{-1} \cdot \mathrm{h}^{-1}$ por período de oito horas como auxiliar no desmame ventilatório com sucesso e sem sinais da SIP. Esses autores sugeriram que a infusão com doses moderadas ou baixas e por curto tempo, horas e não dias, poderia ser usada em pacientes pediátricos com segurança. Nesse contexto de doses baixas a moderadas Sloan ${ }^{12}$ chegou a referir que para procedimentos curtos em crianças com doenças mitocondriais musculares é mais seguro o uso do propofol do que dos agentes halogenados, barbitúricos e do óxido nitroso. Rigby-Jones e col. ${ }^{13}$, em seus estudos farmacocinéticos com crianças gravemente enfermas sugeriram como segura uma dose até $4 \mathrm{mg} \cdot \mathrm{kg}^{-1} \cdot \mathrm{h}^{-1}$, porém é importante lembrar que seus pacientes foram observados após a realização de procedimentos cirúrgicos cardíacos ${ }^{14}$.

\section{CONCLUSÃO}

O propofol deve ser usado com cautela quando se planeja o seu uso sob regime de infusão contínua por períodos prolongados. O aparecimento de sinais sugestivos da síndrome da infusão do propofol exige a suspensão imediata do fármaco e início de medidas de suporte.

\section{Propofol Infusion Syndrome}

Fabiano Timbó Barbosa, TSA, M.D.

\section{INTRODUCTION}

Propofol was introduced in clinical practice in 1977 exclusively as an intravenous drug to be used to induce anesthesia ${ }^{1}$. Fast awakening of patients, even after prolonged infusion, called the attention of researchers for other uses ${ }^{1}$. This drug has slowly replaced barbiturates to sedate patients on mechanical ventilation in intensive care units, with 
the advantage that it can protect the brain of patients hemodynamically unstable ${ }^{2}$.

The first reports compatible with the propofol infusion syndrome (PRIS), with a high mortality rate, appeared when its use became more widespread ${ }^{1}$.

\section{PHARMACOKINETICS AND PHARMACODYNAMICS OF PROPOFOL}

Propofol, or 2,6 diisopropylphenol, is relatively insoluble in water $^{3}$. It is commercialized as $1 \%$ or $2 \%$ milky, white solution containing $10 \%$ soy oil, $2.25 \%$ of glycerol, and $1.2 \%$ of purified egg phosphates ${ }^{4}$. The presence of organic components makes it possible to be contaminated, but the addition of EDTA added more safety to its administration ${ }^{4,5}$. Some pharmacokinetic models suggested a distribution half-life between 2 and 4 minutes, and 1 to 3 hours of elimination half-life $\left(T_{1 / 2} \beta\right)^{4,5}$. It has hepatic and extra-hepatic metabolism ${ }^{3-5}$, probably in the lungs ${ }^{3}$, since its rate of degradation is higher than the hepatic blood flow ${ }^{4,5}$. It forms inactive sulfates and glucuronides ${ }^{4,5}$. Its $T_{1 / 2} \beta$ is slightly elevated in the presence of liver disease ${ }^{4}$.

Propofol is eliminated in the urine, but there is little change in its pharmacokinetics in case of kidney disease ${ }^{4-6}$.

Children need higher doses due to the larger volume of distribution in the central compartment and higher clearance; the opposite is true for the elderly ${ }^{4,5}$.

More than one mechanism of action has been proposed for propofol. It potentiates the central inhibition of gamma-aminobutyric acid on its type $A$ receptor, blocks the ion channel in the cerebral cortex and central nicotinic receptors, and inhibits the signaling of lysophosphatidate in receptors of lipid mediators ${ }^{3}$.

This drug has a direct depressive action in the cardiovascular system, and it also decreases the tone of catecholamines, besides inhibiting the baroreceptor ${ }^{3-5}$. It depresses the vascular smooth muscle and reduces pre- and post-load ${ }^{4}$. Propofol reduces intracranial pressure, brain blood flow, and brain oxygen consumption, protecting the central nervous system ${ }^{3-5}$. However, it can also decrease cerebral perfusion pressure due to its hemodynamic effects ${ }^{4}$. It preserves the reactivity of cerebral vessels to carbon dioxide $\left(\mathrm{CO}_{2}\right)$ and cerebral self-regulation ${ }^{3-5}$. Evidences have demonstrated that it has anticonvulsant properties, although this property is controversial ${ }^{4}$.

Propofol causes central respiratory depression and reduces respiratory response to $\mathrm{CO}_{2}$ and hypoxemia ${ }^{3-5}$. It causes bronchodilation in patients with chronic obstructive pulmonary disease, and it does not inhibit pulmonary vasoconstriction to hypoxemia ${ }^{3}$.

Its actions in the immune system are controversial. Some authors suggested it has a beneficial action in patients with endotoxemia, but others demonstrated a reduction in interleukin-8 formation, with inhibition of the immune system ${ }^{4,5}$.

\section{PROPOFOL INFUSION SYNDROME}

Propofol infusion syndrome is a set of adverse events, almost always fatal, that occur after continuous infusion of high doses of propofol. It affects adults and children, although it seems to be more frequent in children ${ }^{1}$.

Clinical and laboratorial changes related to the syndrome include heart failure ${ }^{1,6-8}$, arrhythmias ${ }^{1}$, metabolic acidosis ${ }^{1,8}$, hypertriglyceridemia ${ }^{1}$, rhabdomyolysis ${ }^{6-8}$, and renal failure ${ }^{6,8}$. Fatty infiltration of the liver ${ }^{1,6}$, lungs, and other organs ${ }^{6}$ is also present. Muscle biopsy might reveal necrotic areas along with regenerating areas, compatible with myonecrosis ${ }^{1}$.

The physiopathology of the propofol infusion syndrome is not completely understood. Some theories proposed include: inhibition of mitochondrial activity by decreasing the activity of cytochrome $\mathrm{C}$ oxidase ${ }^{1,10}$ and by failure in the oxidation of fatty acids ${ }^{8-10}$, blockade of beta-adrenergic receptors ${ }^{8-10}$, and the presence of a toxic metabolite in the tissues ${ }^{1,10}$. The last hypothesis is not accepted by all authors as being possible because there is evidence that the known metabolites of propofol do not have clinically significant activity ${ }^{1}$.

The doses mentioned in the literature as being capable of triggering the propofol infusion syndrome are greater than 5 $\mathrm{mg} \cdot \mathrm{kg}^{-1} \cdot \mathrm{h}^{-1}$ for a period of more than 48 hours ${ }^{2,6,10}$. Although this is the classic description, it has been described the development of the syndrome in an adult after 12 hours of infusion of high doses, in a child after 6 hours ${ }^{8}$, and after 4 hours during anesthesia after the accidental use of 44.7 mg. $\mathrm{kg}^{-1} \cdot \mathrm{h}^{-1}$ in a 6 -month old child ${ }^{7}$.

The main risk factors associated with this syndrome seem to be the dose and the duration of the infusion, and it is also possible that the concentration of the solution plays a role ${ }^{1}$. Recently, the concomitant use of corticosteroids ${ }^{8}$ or vasoactive amines ${ }^{9}$ with propofol has also been implicated as a predisposing factor. Elevated levels of catecholamines have been related to the ventricular dysfunction that occurred in some cases ${ }^{9}$.

Treatment of the propofol infusion syndrome includes the immediate discontinuation of the drug, support measures, and dialysis. When dialysis can not be used, mortality reaches $100 \%{ }^{1}$.

In a study by Sheridan et al. ${ }^{11}$ with burned children, continuous infusion of propofol, with mean doses of $3.6 \pm 2.9 \mathrm{mg} \cdot \mathrm{kg}^{-1} \cdot \mathrm{h}^{-1}$ for 8 hours, was successfully used to help weaning off mechanical ventilation, without signs of the propofol infusion syndrome. The authors suggested that infusion of moderate to low doses of propofol for a short period, hours instead of days, could be safely used in children. In this context of low to moderate doses, Sloan ${ }^{12}$ reported that propofol is safer than halogenated agents, barbiturates, and nitrous oxide for short procedures in children with muscular mitochondrial disorders. In their pharmacokinetic studies in severely ill children, Rigby-Jones et al. ${ }^{13}$ suggested that doses of up to 4 $\mathrm{mg} \cdot \mathrm{kg}^{-1} \cdot \mathrm{h}^{-1}$. are safe; but one should remember that their patients were observed after cardiac surgeries ${ }^{14}$. 


\section{CONCLUSION}

Propofol should be used carefully when it is to be administered as a continuous infusion for long periods. The development of signs suggestive of the propofol infusion syndrome is an indication that the infusion should be discontinued immediately and the institution of support measures initiated.

\section{REFERÊNCIAS - REFERENCES}

01. Bray RJ - The propofol infusion syndrome in infants and children: can we predict the risk? Curr Opin Anaesthesiol, 2002; 15:339-342.

02. Warner DS - Long-term propofol infusion and cardiac failure in adult patients with head injuries. J Neurosurg Anesthesiol, 2001; 13:344.

03. Chiu JW, White PF - Anestesia Intravenosa Não-Opióide, em: Barash PG, Cullen BF, Stoelting RK - Anestesia Clínica. 4를 Ed. São Paulo, Manole, 2004;327-344.

04. Bagatini A, Falcão ACCL, Albuquerque MAC - Propofol, em: Duarte NMC, Bagatini A, Anzoategui LC - Curso de Educação a Distância em Anestesiologia. São Paulo, Segmentofarma, 2005;143-160.

05. Sarmento RFO - Propofol, em: Cavalcanti IL, Cantinho FAF, Vinagre RCO - Anestesia Venosa. Rio de Janeiro, SAERJ, 2004; 39-54.

06. Moritz RD - Sedação e analgesia em UTI. RBTI, 2005;17:52-55.

07. Patermann B, Buzello S, Duck $M$ et al. - Accidental tenfold overdose of propofol in a 6-month old infant undergoing elective craniosynostosis repair. Anaesthesia, 2004;59:912-914.

08. Liolios A, Guerit J-M, Scholtes J-L et al. - Propofol infusion syndrome associated with short-term large-dose infusion during surgical anesthesia in an adult. Anesth Analg, 2005;100:18041806.
09. Cobett SM, Moore J, Rebuck JA et al. - Survival of propofol infusion syndrome in a head-injured patient. Crit Care Med, 2006; 34:2479-2483.

10. Coetzee JF, Coetzer M - Propofol in paediatric anaesthesia. Curr Opin Anesthesiol, 2003;16:285-290.

11. Sheridan RL, Keaney T, Stoddard F et al. - Short-term propofol infusion as an adjunt to extubation in burned children. J Burn Care Rehabil, 2003;24:356-360.

12. Sloan IAJ — Propofol syndrome in children. CMAJ, 2003; 168:669.

13. Rigby-Jones AE, Nolan JA, Priston MJ et al. - Pharmacokinetcs of propofol infusion in critically ill neonates, infants, and children in an intensive care unit. Anesthesiology, 2002;97:1393-1400.

14. Baun VC - Pharmacokinetcs of propofol infusion in critically ill neonates, infants, and children in an intensive care unit. Surv Anesthesiol, 2003;47:315-316.

\section{RESUMEN}

Barbosa FT — Síndrome de la Infusión del Propofol.

JUSIFICATIVA Y OBJETIVOS: El síndrome de la infusión del propofol ha sido descrito como un síndrome raro y frecuentemente fatal que ocurre después de la infusión prolongada de ese fármaco. Puede resultar en acidez metabólica grave, rabdomiólisis, colapso cardiovascular y deceso. El objetivo de este artículo fue mostrar aspectos relacionados al síndrome de la infusión del propofol a través de la revisión de la literatura.

CONTENIDO: Están definidas las características del síndrome de la infusión del propofol en cuanto a la fisiopatología, características clínicas, tratamiento y recomendaciones de dosis para pacientes gravemente enfermos.

CONCLUSIONES: El propofol debe ser usado con cautela cuando se planea su uso bajo el régimen de infusión continua por períodos prolongados. El aparecimiento de señales sugestivas del síndrome de la infusión del propofol indica la suspensión inmediata del fármaco y el inicio de medidas de soporte. 